\title{
Estetic And Symbolic Study Of Installation Art Works In Sedekah Gunung Merapi Ritual In Selo Boyolali
}

\author{
Purwanto $^{1}$, Tjetjep Rohendhi Rohidi ${ }^{2}$ Triyanto $^{3}$ \\ \{purwanto_senirupa@mail.unnes.ac.id ${ }^{1}$ \} \\ Faculty Languages and Art, Universitas Negeri Semarang \\ Kampus Sekarang Gunungpati Semarang 50229, Indonesia
}

\begin{abstract}
The Selo community of Boyolali Regency has a ritual tradition of Alms Mountain Merapi, which is held on the first of Mukharam. Enlivening the ritual activities was held the festival of installation art, which was attended by local artists in the region. The activity of the installation art festival is an interesting cultural activity to study, considering that the work of installation art is an activity in the terminology of contemporary art, while the orientation of the Selo community during this time in cultural activities has always been tradition-oriented. The objectives of this study are: Understanding and explaining the aesthetic and symbolic values of installation art by the Selo Boyolali community which was made to enliven the charity rituals of Mount Merapi. The method used in this study selected a qualitative case study approach with descriptive methods. The technique of obtaining data is done by observation, interviews, and documentation. The procedure of data analysis is taken through the process of data reduction, data presentation and verification of data and conclusions. In this verification process to sharpen and expand and validate the interpretation, confirmation must be made with the theory and methodology used. The results showed that basically Javanese aesthetic characteristics are: mystical, magical, cosmic, and religious, originating from cultural values: 1) Cosmological, 2) Symbolic classification, and 3) orientation of people's lives. That aesthetic principle is used as the basis for the creation of installation artwork. The symbolic meaning of the installation artwork is basically an expression of respect, attention and effort to nurture the earth, or 'memayu rahayuning bawana'.
\end{abstract}

Keywords: installation art, aesthetics, rituals, mountain alms

\section{Introduction}

The Selo community in Boyolali Regency carries out the Merapi mountain alms ritual on the first of Mukharam. The implementation of the Merapi mountain charity ritual tradition has now become a major cultural event, not only dealing with ritual functions that are transcendental but also have functions in complex social dimensions. Related to the ritual tradition activities, there are also art party activities, in the form of cultural procession and staging of traditional arts owned by each hamlet, as well as the festival of installation art. The activity of the installation art festival held in 2017 was attended by eight groups of local artists, who were well organized along the main road in Selo sub-district, from the Tritisan hamlet to the New Selo area.

The installation art festival as part of the Mountain Alms ritual is a symbolic manifestation that reflects the orientation, and way of thinking of the community. The influence of the 
environment in the cultural life of community groups is a necessity, which characterizes the orientation of fulfilling their life needs, including aesthetic needs. Forde (in Suparlan, 1980) suggests that the relationship between human activities and their natural environment is bridged by cultural patterns that humans have. By using this culture, humans try to adapt to their environment. In the adaptation process, humans utilize their environment to continue to live their lives. As individuals in a community, in order to survive and still be able to maintain their existence inevitably they must be able to follow and take advantage of their socio-cultural conditions, as well as play a role in coloring the social life in their community. Rohidi (1993: 2) states that every society, both consciously and unconsciously, develops art as an expression of an aesthetic sense that stimulates it in line with the views, aspirations, needs, and ideas that dominate it.

The phenomenon of installation art is actually a manifestation of contemporary art or sometimes referred to as postmodenism. Postmodernism is a concept of periodization which serves to connect the emergence of new formal forms in the cultural joint with the birth of a type of social life and a new economic order; what is euphemistically referred to as the modernization of post-industrial or consumer society, media society or spectacle, or multinational capitalism. The postmodern ethos rejects harmonious, universal and consistent explanations. They replace all of this with respect to differences and rewards to special (particular and local) and discard universal ones. Postmodernism rejects the emphasis on scientific discovery through the method of science, which is the intellectual foundation of modernism to create a better world. Basically, postmodernism is anti-modern (Piliang 2003). What about installation works made by residents of the Selo community, which in fact they are traditionally cultured communities, may be an interesting focus of study.

In particular, this research seeks to understand broadly and deeply the aesthetic form of the installation art of the Selo community, and to understand the symbolic meanings that exist in it. By using theoretical analysis in an interdisciplinary manner, it is expected to be able to obtain substantive and holistic truths.

This research is important to be carried out with the following reasons: 1) it can be used as a foundation in the development of culture carried out by the government, so that the direction of the development of the culture runs wisely and does not damage the cultural values of the community. 2) can reveal the specific uniqueness of the visual phenomenon of installation art from its aesthetic and symbolic aspects, as well as its functional value for the community. 3) Offering a dialectic space for contemporary art that is currently seeking identity.

\section{Methods}

This research uses a descriptive qualitative approach. Data were collected by interview, observation, and document study. The collected data are analyzed using flow analysis from Miles and Huberman, in Rohidi (1992), using measures including data reduction, data display, and conclusion drawing / verification 


\section{Results and Discussion}

Rohendi (1994: 23) states that culture exists, develops, and is standardized in the social traditions of a society. Culture belonging to the community is used together as a guideline or frame of reference for citizens to behave to fulfill their needs. This includes fulfillment of aesthetic needs. Or it can be said that the social behavior of a community group will not be free from its culture.

The activities of the installation festival on the tradition of the Mount Merapi alms ritual in Selo Boyolali reflect the aesthetic taste that is always integrated with various other factors including the living environment, needs, and institutions in the lives of its people. Khayam (1981: 38) states that art is never independent of society. As an important part of culture, art is an expression of the creativity of the culture itself. Humans as individuals an integral part of society and culture carry out functions as a buffer of culture - as well as the arts that exist in their communities

The Selo Boyolali community basically has the characteristics of a Javanese culture group. (Purwanto 2009, Magnis Suseno, Franz. 1996) explained that the characteristics of Javanese culture are: 1) Living as an agrarian society, 2) maintaining a harmonious life towards nature both physically and non-physically, in harmony, harmony and balance. 3) using Javanese as a mother tongue. 4) Use symbolic classification for determine ethically and unethically and aesthetically and not aesthetically, based on subtle, right-left, bottom-down, front-back, etc. The word smooth, right, top, front is a representation of something that is positive, while the harsh words, left, down, and back represent negative traits. 5) Cosmological orientation towards the relationship with the environment around and with the Lord, the nature of order, order, discipline, and the same as a measure of the stability of life. 6) Mystical, in looking and behaving towards nature and God. 7) As well as being oriented towards fulfilling spiritual needs not material.

Triyanto (2008) explains that there are three Javanese aesthetic characteristics that are derived from cultural values, namely; cosmology, symbolic classification, and orientation of community needs. The aesthetic presentation of Javanese art is characterized by cosmology, magic, mystic, symbolic, and religious. These characteristics become spirit or soul in every aspect of his art. The aesthetic expression of installation art made by the Selo Boyolali community basically reflects the characteristics this aesthetic. Can be explained as follows.

Work specifications: Title ' Topeng Ireng', Media: scrap metal, size: $4 \times 3 \mathrm{~m}$.

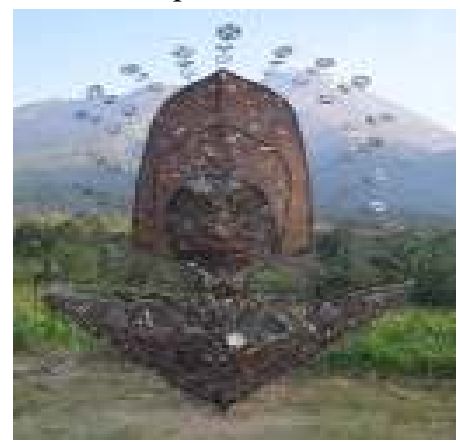

Aesthetic analysis: inspired by the form of the traditional dance figure "Mask Ireng", which has magical, mystical, and creepy features. The form elements are arranged rhythmically on a regular basis, and are placed using a balance of symmetry well, as is the specific taste of Javanese aesthetic balance. The work became a dominance in its environment, and seemed monumental. 
Work specifications: title 'Abstraksi Kuda Lumping' Media: Metal, size: 3x3m. standing on a $3 \mathrm{~m}$ high pole.

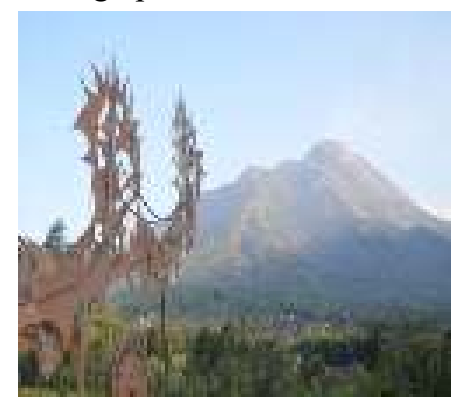

Aesthetic analysis: the form of the work is very concerned about its harmony with its natural environment, sourced from the form of Kuda lumping that characterize the potential of traditional arts possessed by the Selo community. The elements are unique, arranged in a symbolic decorative arrangement. Rhythm is built in accordance with the natural rhythms that are organic.

Work specifications: Title, 'Semar Sang Pamomong', Media, bamboo, plywood and rope. Area of $20 \times 20 \mathrm{~m}$.

Aesthetic analysis: displays the main subject of the Semar puppet character, as a pamomong

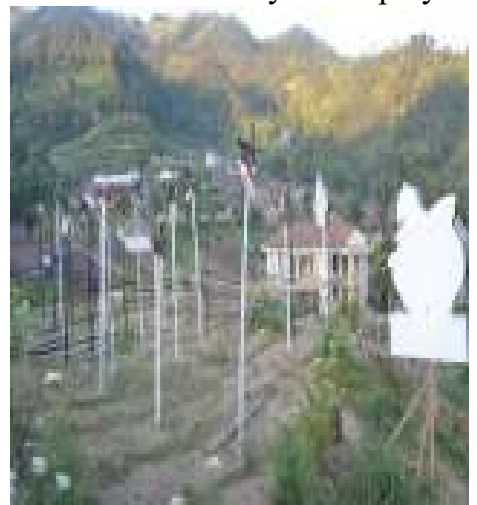
figure for the creation of earth peace.

With the ropes in his hand he controls the establishment of $5 \mathrm{~m}$ high white bamboo poles with 12 poles, and 12 poles which are black, at the end of the pole is placed a kitiran with the form of accessories of clowns as well as Gareng and Petruk figures, as well as the form of puppet mountains. Semar's figure becomes a center for life regulators who are both (white) and evil (black) characters, all arranged to achieve a harmony life. The installation works seem mystical, ecological, and symbolic, and are very laden with messages in the perspective of the values of the orientation of Javanese society.

Specifications of the work: title, 'Kidung Rahayu', Media, wooden branches, bamboo, hard and cloth, size of area $5 \times 10 \mathrm{~m}$.

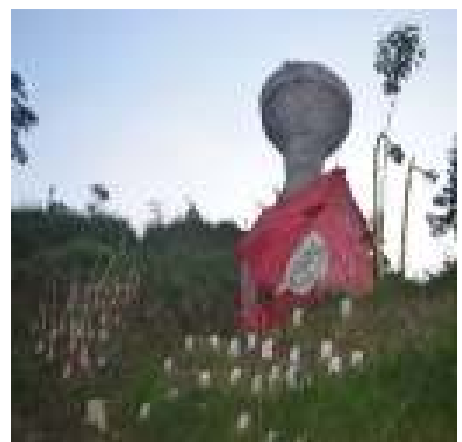

Aesthetic analysis: the dominance of the subject of this work on the shape of a red house with a big chimney, as a symbol of the entry of blessings from the Lord of the universe, which provides protection for life. At the bottom there are inscriptions of Javanese letters arranged in reverse as a manifestation of 'Rajah Kalacakra' which functions as 'refuse' or to prevent the arrival of distress, or evil forces that will ruin life. This installation artwork is a symbol of transcendental communication and a manifestation of prayer to God to get salvation in life. The characteristics of the work are religious, mystical, magical, and cosmic transcendental.

Work specifications: Title, 'Sedekah Bumi', paper media, size, applied to trees that line 100m 


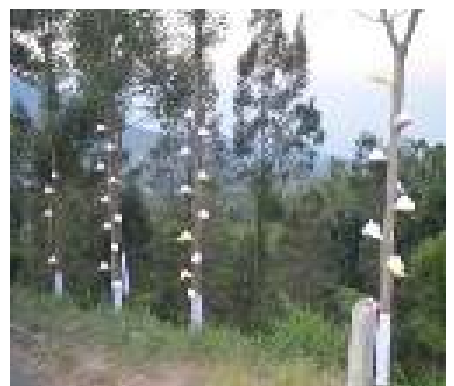

Aesthetic analysis: The installation work of art presents the form of rice packets called 'Penakkan' as a characteristic feature of a Javanese rice wrapper. The rice package is usually given when the person finishes the feast, which is commonly referred to as kenduri or sedekahan rice. The shape of the white package is arranged rhythmically along the road to the New Selo area. The white look contrasts with the green color of the environment so it is magical, poetic, religious, transcendental and cosmic.

Work specifications: Title 'Pepethan ', media, bamboo, fabric, and paint, the size of the work is

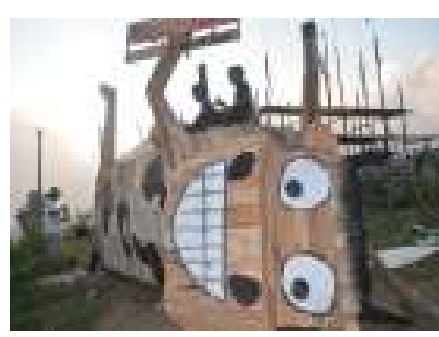

and very beautiful selhuette.

$2.5 \mathrm{~m}$ long and $10 \mathrm{~m}$ long.

Aesthetic analysis: Pepethan is the formation of fantasy figures from astral beings. Pepethan usually has the characteristics of large eyes, large teeth, and looks creepy. Pepethan is the cultivation of the guardian astral or ruler in an area, so it is made with characteristics, ideoplastic, mystical, magical, transcendental, and cosmic. This installation artwork was placed on a hill, so that it appeared from a distance, when at dusk the shape of Pepethan turned into a very monumental

Works specifications: Title 'Punakawan', Triplex media, Size $2 \times 2 \mathrm{~m}$ number 2 units. Aesthetic

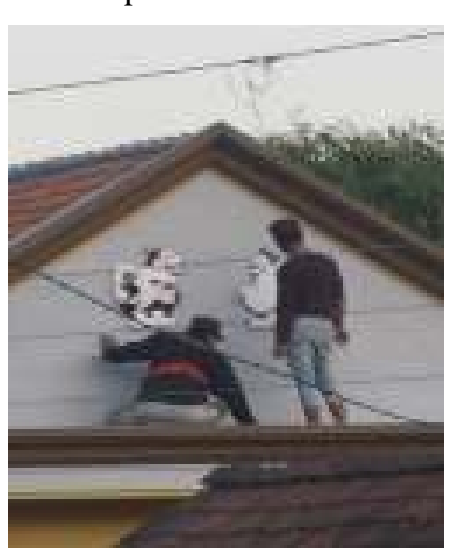
analysis: it appears in the picture that two people are installing installation artwork on the upper wall part of the house with figures from Punakawan wayang. Punakawan in wayang is known as a representation of small people, so the figure is very close and liked even synonymous with the Selo community. So when they put up the Punakawan figure it seemed they were giving honor to themselves. The figure of the clownman in the perspective of the cosmology of the Selo community became a balance figure of the life of the universe. When Punakawan figures emerge, they create an optimistic order, happiness and new hopes. Characteristics of a caricature that are funny, simple, and express egalitarian characteristics. Many of these installation artworks are found in the homes of the Selo people, who have the impression of friendliness, openness, well come for everyone, as is characteristic of Javanese culture. 


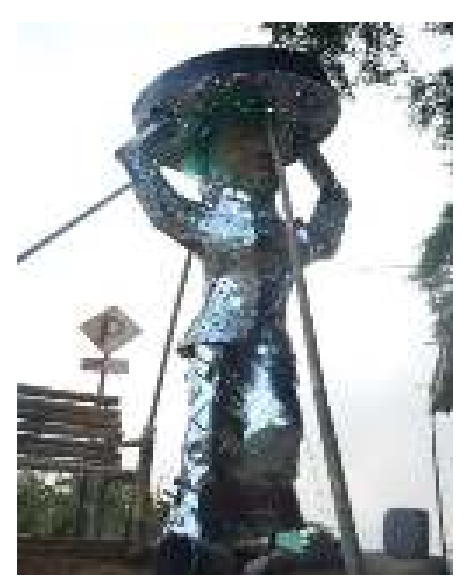

Specifications of work: the title of the work 'Sadranan', metal media, size $3 \mathrm{~m}$. Aesthetic analysis: Sadranan is a traditional ritual that is performed by Selo community every the month Sha'ban as a tribute to ancestral spirits. During the ritual people flocked (mothers) to bring 'tenong' which contained food brought to the ancestral tomb. In the tomb they prayed and then continued to eat together. In this installable art work, it reflects the image of a mother carrying a tenong / food place, looking very excited in carrying out the traditional ritual. The shape of the figure in this work tends to be impressive and glamorous due to the effect of the media used in silver. The work looks monumental, beautiful, but still seems magical and cosmic.

A symbol has meaning for those who use it (Bachtiar 1987). That way, the Selo community itself can understand the symbolic meaning of the installation work. They stated that the forms of the installation work were expressed as a respect for the environment both physical and nonphysical that they have, as well as a medium of prayer and the hope of the Selo people to be kept away from disasters and given prosperity in their natural lives. The point of the content of the work is the community's efforts to protect the earth so that life can be sustainable.

Hopefully this artistic spirit of the Selo community is important to be discussed in broad life, hoping to inspire other artists to maintain the importance of harmony in life. Novelty of this study found substantive truths reinforce the theory, that human behavior including in it is in meeting its aesthetic needs is always shaded by its culture

\section{Conclusion}

Installation art is a manifestation of contemporary art, but for the traditional artists in Selo Boyolali as an expression of expression that actually reinforces its traditional existence. The installation art by the traditional artist Selo Boyolali is more uplifting the values of locality, including spirit, material, form structure and symbolism. In the installation art works there are expressions of aesthetic forms and symbolic content that reflect the value of the Selo community's life tradition, as a Javanese culture. The symbolic construction of the work reflects the enthusiasm of the community to protect, care for and protect the earth to be sustainable. May awareness and enthusiasm to conserve the environment become important in today's life, in the midst of many groups of people who still tend to do environmental damage in order to carry out and maintain their lives. 


\section{References}

[1] Bachtiar, Harsya, Budaya dan Manusia Indonesia, Yogyakarta: Hadininda Graha Widya. 1987.

[2] Irianto, Asmujo Jono.. Warisan Tradisi dan Seni Kontemporer. Makalah Seminar Nasional. Pengembaangan Kesenian Tradisional dalam Kebudayaan Kontemporer. Unnes. Semarang. 2009

[3] Kayam, Umar. Seni, Tradisi, Masyarakat. Sinar Harapan. Jakarta. 1981.

[4] Miles, B \& Hubberman.. Analisis Data Kualitatif. (Terjemahan, Rohidi, TR.) UI Press. Jakarta. 1992

[5] Piliang, Y. A. Hipersemiotika Tafsir Cultural Studies Atas Matinya Makna. Yogyakarta: Jalasutra. 2003.

[6] Purwanto, Gambar Wayang Buatan Anak-Anak SD Islam Siti Sulaechah Mayangsari Semarang: Ekspresi Kultural Anak-Anak Pada Lingkungan Masyarakat, Skripsi, PPs. UNNES. Semarang. 2009

[7] Rohidi, Tjetjep Rohendi. 1993. Kesenian Dalam Pendekatan Kebudayaan. STISI Bandung Press. Bandung.

[8] ........... Kesenian Tradisional Nusantara. Makalah Seminar Nasional Pengembangan Kesenian Tradisional Dalam Kebudayaan Kontemporer. Unnes. Semarang.1994

[9] Suparlan, Parsudi Manusia, Kebudayaan, dan Lingkungannya: Perspektif ntropologi Budaya. Makalah dalam Seminar Manusia Dalam Keserasian Lingkungan. PSLUI. Jakarta. 1980.

[10] Susanto, Mikke.. Diksi Rupa. Kumpulan Istilah dan Gerakan Seni Rupa. Yogyakarta: Dicti Lab. Yogyakarta \& Jagad Art Space, Bali. 2011

[11] Triyanto Estetika Nusantara: Sebuah Perspektif Budaya, Imajinasi, Vol. 4 No: 1, Semarang, UNNES. 2008. 